\title{
Genetic characterization of Red Junglefowl (Gallus gallus), Thai indigenous chicken (Gallus domesticus), and two commercial lines using selective functional genes compared to microsatellite markers
}

\author{
P. Akaboot ${ }^{1,5}$, M. Duangjinda ${ }^{1,2,5}$, Y. Phasuk ${ }^{1}$, C. Kaenchan ${ }^{3}$ and \\ W. Chinchiyanond ${ }^{4}$
}

${ }^{1}$ Department of Animal Science, Khon Kaen University, Khon Kaen, Thailand ${ }^{2}$ Research and Development Network Center for Animal Breeding (Native Chicken), Khon Kaen University, Khon Kaen, Thailand

${ }^{3}$ Chulabhorn Wildlife Breeding Center, Department of National Parks, Wildlife and Plant Conservation, Sisaket, Thailand

${ }^{4}$ Khao Kho Wildlife Captive Breeding Center, Department of National Parks, Wildlife and Plant Conservation, Phetchabun, Thailand

${ }^{5}$ Center of Excellence on Agricultural Biotechnology (AG-BIO/PERDO-CHE), Bangkok, Thailand

Corresponding author: M. Duangjinda

E-mail: monchai@kku.ac.th

Genet. Mol. Res. 11 (3): 1881-1890 (2012)

Received August 19, 2011

Accepted January 18, 2012

Published July 19, 2012

DOI http://dx.doi.org/10.4238/2012.July.19.7

ABSTRACT. Genetic characterization among Red Junglefowl (GS, Gallus
gallus spadiceus), Thai indigenous chicken (TIC, Gallus domesticus) and
commercial lines has been widely used for studies of genealogical origin,
genetic diversity, and effects of selection. We compared the efficiency of
genetic characterization of chicken populations that had been under different
intensities of selection using selective functional gene versus microsatellite 
marker analyses. We genotyped 151 chickens from five populations: Red Junglefowl, TIC and commercial lines (BR, broiler and WL, White Leghorn). Genetic structure analyses using six loci of five functional genes - corresponding to heat tolerance (heat shock protein 70, HSP70/C, $H S P 70 / \mathrm{M}$ ), broodiness (vasoactive intestinal peptide receptor-1, VIPR-1), egg production-[24-bp indel (insertion or deletion) prolactin, 24bpPRL], ovulation rate (growth hormone receptor, GHR), and growth (insulin-like growth factor-1, $I G F-1)$ - were compared with 18 microsatellite markers. PCR-RFLP and allele specific PCR were used for functional gene typing. A neighbor-joining tree from Nei's genetic distance was constructed to show genetic relationships. A similar pattern was found with both functional genes and microsatellites. Three groups consisting of BR, WL and TIC-GS-GG were formed. A principal component plot based on individual similarity using Dice's coefficient was also constructed to confirm the relationship. Different patterns were found when using functional genes versus microsatellites. A principal component plot with functional genes also gave three clusters consisting of BR, WL and TIC-GS-GG. A principal component plot using microsatellites gave four clusters, consisting of WL, GG, TIC, and BRGS. Characterization of BR and GS differs from previous studies. We concluded that genetic characterization with appropriate functional genes is more accurate when differences in genetic make-up among populations are known. Genetic characterization using functional gene data was consistent in neighbor joining and principal component plot analyses, while genetic characterization using microsatellite data gave varied results depending on the analysis methodology.

Key words: Genome comparisons; Genetic structure; Genetic diversity; Genetic characterization

\section{INTRODUCTION}

Genetic diversity refers to the existence of genetic variants among genomes of individuals, families, strains, and populations. Under evolution or genetic selection, this may cause changes in genetic makeup, and even the repair or loss of genes associated with specific characteristics. Thus, an assessment of genetic variations and genetic distances among original indigenous and commercial strains can be useful. Genomics analysis may facilitate the sustainable management and utilization of chicken genetic resources. For this purpose, molecular tools provide useful information for initial evaluation of genetic resources (Weigend and Romanov, 2001). It is now believed that domestic chickens originated from Red Junglefowl (RJF; Gallus gallus) in Southeast Asia around Thailand (Fumihito et al., 1994; Niu et al., 2002; Hillel et al. 2003); hence, Thai indigenous chickens (TIC) may be regarded as the original domesticated chickens. Okumura et al. (2006) showed that native chickens from Thailand, Indonesia and Laos were closer to RJF than to broilers (BR) and White Leghorn (WL). Due to commercial breeding programs, the genetic structures of RJF, TIC and commercial chickens (CC) should be different due to different selection pressures.

Recently, RJF in Thailand has been designated as an endangered species; it is found 
only in forested hills or within national parks. Only natural selection and genetic drift occur in the RJF population. The TIC ( $G$. domesticus) is defined as a native species and is generally found in small villages, where farmers typically raise them for cockfighting and family consumption. There is no existing selection program, but slight phenotypic selection by owners might occur in the population. BR and WL are defined as high-selection pressure populations due to their selection programs for commercial meat and egg production.

Microsatellites have been used extensively to examine genetic diversity within and between different fowl populations (Weigend and Romanov, 2001; Delany, 2003). The FAO/ ISAG (1998) recommendation of at least 25 microsatellite loci with 4-10 observed alleles per locus and 25 individuals per breed for effective investigation of genetic diversity is expensive and time-consuming. However, functional gene analysis by PCR-RFLP and by allele-specific PCR has demonstrated genetic differentiation, speciation and an evolutionary process among populations (Soller et al., 2006).

It would be useful if genetic analysis with a suitable set of functional genes could be compared with microsatellite techniques for genetic characterization. We compared the efficiency of two molecular tools (functional genes versus microsatellite analysis) for estimating the genetic relationships of various fowl populations under varied intensities of genetic selection. We used six loci of five functional genes associated with heat tolerance (heat shock protein 70, HSP70/C, HSP70/M; Duangduen, 2008), mothering ability (vasoactive intestinal peptide receptor-1, VIPR-1; Zhou et al., 2008), egg production [24-bp indel (insertion or deletion) prolactin, 24bpPRL], and growth hormone receptor, GHR; Cui et al., 2006 and Li et al., 2008, respectively), and growth performance (insulin-like growth factor-1, IGF-1; Zhou et al., 2005) to characterize the genetic structures of RJF, local domestic chickens (TIC) and commercial chickens $(\mathrm{CC})$ undergoing different selection and breeding strategies.

\section{MATERIAL AND METHODS}

\section{Animals and DNA isolation}

The study was carried out with: two subspecies of RJF, G. gallus $(\mathrm{GG}, \mathrm{N}=30)$ and $G$. g. spadiceus $(\mathrm{GS}, \mathrm{N}=31)$ from the Thailand National Park, Wildlife and Plant Conservation Department in collaboration with the Wildlife Conservation Office; a variety of TIC, G. domesticus Pradu Hang Dam (PD, N = 30) from the Research and Development Network Center for Animal Breeding (native chicken), and commercial lines $[\mathrm{BR}(\mathrm{N}=30)$ and $\mathrm{WL}(\mathrm{N}=30)]$ from a private company and from Khon Kaen University farm, respectively. One milliliter of blood was collected from the wing vein of individual birds; each sample was placed in a microtube containing $10 \% 0.5 \mathrm{M}$ EDTA as an anticoagulant. DNA was isolated as described by Goodwin et al. (2007).

\section{PCR conditions}

PCR-RFLP and AS-PCR-primers for functional gene analysis are described in Table 1. Eighteen microsatellite markers were selected, based on the recommendations of FAO/ISAG (1998) and prior studies by Rosenberg et al. (2001), Hillel et al. (2003), Beigi Nassiri et al. (2007), Tadano et al. (2007), and Li et al. (2009). Microsatellite markers were distributed on autosomes, as presented in Table 2 . The PCR was performed in a $10-\mu \mathrm{L}$ mixture containing: $1 \mu \mathrm{L} 50$ ng genomic 
DNA, $1 \mu \mathrm{L}$ 10X PCR buffer, $1 \mu \mathrm{L} 3 \mu \mathrm{M}$ primers, $1 \mu \mathrm{L} 1 \mathrm{mM}$ of each dNTP (Promega, USA), 0.8 $\mu \mathrm{L} 25 \mathrm{mM} \mathrm{MgCl}$, and $0.1 \mu \mathrm{L} 5 \mathrm{U}$ Taq DNA polymerase (RBC Bioscience, Taiwan). The PCR was run with the following conditions: $5 \mathrm{~min}$ at $94^{\circ} \mathrm{C}$, followed by 30 cycles of $30 \mathrm{~s}$ at $94^{\circ} \mathrm{C}, 30-45 \mathrm{~s}$ at melting temperature in ${ }^{\circ} \mathrm{C}$, and $45-90 \mathrm{~s}$ at $72^{\circ} \mathrm{C}$, with a final extension of $5 \mathrm{~min}$ at $72^{\circ} \mathrm{C}$. A gel documentation system (Syngene, UK) was employed for scoring the bands for individual genotypes.

Table 1. Selected functional genes and associated characteristics of the chickens.

\begin{tabular}{|c|c|c|c|c|c|}
\hline Gene & Primer sequence $\left(5^{\prime}-3^{\prime}\right)$ & Associated character & $\operatorname{Tm}\left({ }^{\circ} \mathrm{C}\right)$ & PCR length (bp) & Restriction enzyme \\
\hline$H S P 70^{1}$ & $\begin{array}{l}\text { F: AACCGCACCACACCCAGCTATG } \\
\text { R: CTGGGAGTCGTTGAAGTAAGCG }\end{array}$ & Heat tolerance/susceptible & 60 & 360 & $C f r \mathrm{I} / M m e \mathrm{I}$ \\
\hline$V I P R-1^{2}$ & $\begin{array}{l}\text { F: AGAGGAACGCAGCCAGTGC } \\
\text { R: CCCACCTAACATAAAAGCTCAAC }\end{array}$ & Broodiness & 58 & 203 & HaeIII \\
\hline $24 b p P R L^{3}$ & $\begin{array}{l}\text { F: TTTAATATTGGTGGGTGAAGAGACA } \\
\text { R: ATGCCACTGATCCTCGAAAACTC }\end{array}$ & Egg production & 62 & $130 / 154$ & AS-PCR \\
\hline$G H R^{4}$ & $\begin{array}{l}\text { F: GGCTCTCCATGGGTATTAGGA } \\
\text { R: GCTGGTGAACCA ATCTCGGTT }\end{array}$ & Ovulation rate & 62 & 718 & HindIII \\
\hline$I G F-I^{5}$ & $\begin{array}{l}\text { F: CATTGCGCAGGCTCTATCTG } \\
\text { R: TCAAGAGAAGCCCTTCAAGC }\end{array}$ & Growth & 62 & 813 & Hinf I \\
\hline
\end{tabular}

Duangduen (2008); ${ }^{2}$ Zhou et al. (2008); ${ }^{3}$ Cui et al. (2006); ${ }^{4}$ Li et al. (2008); ${ }^{5}$ Zhou et al. (2005). Tm $=$ melting temperature.

Table 2. Description of microsatellites selected to study genetic diversity in chickens.

\begin{tabular}{|c|c|c|c|c|}
\hline Primer & Primer sequence $\left(5^{\prime}-3^{\prime}\right)$ & Motif repeat & $\operatorname{Tm}\left({ }^{\circ} \mathrm{C}\right)$ & Chromosome \\
\hline MCW0014 $2,3,5,6$ & $\begin{array}{l}\text { F: AAAATATTGGCTCTAGGAACTGTC } \\
\text { R: ACCGGAAATGAAGGTAAGACTAGC }\end{array}$ & $(\mathrm{TG})_{18}$ & 60 & 6 \\
\hline MCW00341,2,3,4,5 & $\begin{array}{l}\text { F: TGCACGCGCTTACATACTTAGAGA } \\
\text { R: TGTCCTTCCAATTACATTCATGGG }\end{array}$ & $(\mathrm{TG})_{24}$ & 60 & 2 \\
\hline MCW0037 $7^{1,2,4,5}$ & $\begin{array}{l}\text { F: ACCGGTGCCATCAATTACCTATTA } \\
\text { R: GAAAGCTCACATGACACTGCGAAA }\end{array}$ & $(\mathrm{TG})_{8}$ & 60 & 3 \\
\hline MCW0069 & $\begin{array}{l}\text { F: GCACTCGAGAAAACTTCCTGCG } \\
\text { R: ATTGCTTCAGCAAGCATGGGAGGA }\end{array}$ & $(\mathrm{TG})_{11}$ & 60 & 26 \\
\hline MCW0081 1,2,3,4,5,6 & $\begin{array}{l}\text { F: GTTGCYGAGAGCCTGGTGCAG } \\
\text { R: CCTGTATGTGGAATTACTTCTC }\end{array}$ & $(\mathrm{GT})_{7}$ & 60 & 5 \\
\hline MCW0104 $4^{1,2}$ & $\begin{array}{l}\text { F: TAGCACAACTCAAGCTGTGAG } \\
\text { R: AGACTTGCACAGCTGTGACC }\end{array}$ & $(\mathrm{TG})_{16}$ & 60 & 13 \\
\hline MCW0111 1,2,5 & $\begin{array}{l}\text { F: GCTCCATGTGAAGTGGTTTA } \\
\text { R: ATGTCCACTTGTCAATGATG }\end{array}$ & $(\mathrm{AC})_{8}$ & 60 & 1 \\
\hline MCW0123 $3^{1,3,4}$ & $\begin{array}{l}\text { F: GGAACCACTAGAAAAGAACATCC } \\
\text { R: AATGTGTTTCCACCCCCAAAG }\end{array}$ & $(\mathrm{AC})_{10}$ & 60 & 14 \\
\hline MCW0183 $3^{1,2,4,5,6}$ & $\begin{array}{l}\text { F: ATCCCAGTGTCGAGTATCCGA } \\
\text { R: TGAGATTTACTGGAGCCTGCC }\end{array}$ & $(\mathrm{TG})_{10}$ & 60 & 7 \\
\hline MCW0222 $2^{1,3,4,5}$ & $\begin{array}{l}\text { F: GCAGTTACATTGAAATGATTCC } \\
\text { R: TTCTCAAAACACCTAGAAGAC }\end{array}$ & $(\mathrm{TG})_{10}$ & 60 & 3 \\
\hline MCW02481,2,3,4,5 & $\begin{array}{l}\text { F: GTTGTTCAAAAGAAGATGCATG } \\
\text { R: TTGCATTAACTGGGCACTTTC }\end{array}$ & - & 60 & 1 \\
\hline MCW0295 $1,2,3,4,5,6$ & $\begin{array}{l}\text { F: ATCACTACAGAACACCCTCTC } \\
\text { R: TATGTATGCACGCAGATATCC }\end{array}$ & $(\mathrm{TG})_{10}$ & 60 & 4 \\
\hline ADL112 $2^{2,3,5}$ & $\begin{array}{l}\text { F: GGCTTAAGCTGACCCATTAT } \\
\text { R: ATCTCAAATGTAATGCGTGC }\end{array}$ & $(\mathrm{AC})_{10}$ & 60 & 10 \\
\hline ADL147 ${ }^{4}$ & $\begin{array}{l}\text { F: CTGGTGAATGAGAAGCGATG } \\
\text { R: GCTGCGGCAATAAACTCCCT }\end{array}$ & $(\mathrm{TG})_{9}$ & 57 & 13 \\
\hline ADL268 $1,2,4,5$ & $\begin{array}{l}\text { F: CTCCACCCCTCTCAGAACTA } \\
\text { R: CAACTTCCCATCTACCTACT }\end{array}$ & $(\mathrm{GT})_{12}$ & 60 & 1 \\
\hline ADL0372 & $\begin{array}{l}\text { F: CGCCCCCGTTTACTGATTTG } \\
\text { R: GGCGCCGTTCAAGGAAGCAC }\end{array}$ & $(\mathrm{CA})_{4} \mathrm{GA}(\mathrm{CA})_{9}$ & 60 & 12 \\
\hline LEI0094 $4^{1,2,3,5,6}$ & $\begin{array}{l}\text { F: GATCTCACCAGTATGAGCTGC } \\
\text { R: TCTCACACTGTAACACAGTGC }\end{array}$ & - & 62 & 4 \\
\hline LEI0166 $66^{1,2,3,6}$ & $\begin{array}{l}\text { F: AAGCAAGTGCTGGCTGTGCTC } \\
\text { R: TCCTGCCCTTAGCTACGCAC }\end{array}$ & - & 60 & 3 \\
\hline
\end{tabular}

${ }^{1}$ FAO-ISAG (htpp://dad.fao.org/); ${ }^{2}$ Rosenberg et al. (2001); ${ }^{3}$ Nassiri et al. (2007); ${ }^{4}$ Tadano et al. (2007); ${ }^{5}$ Hillel et al. (2003); ${ }^{6} \mathrm{Li}$ et al. (2009). Tm $=$ melting temperature. 


\section{Statistical analysis}

Genotype and allele frequencies were analyzed using the FSTAT version 2.9.3.2 computer program (Goudet, 2002). Observed heterozygosity $\left(H_{\mathrm{O}}\right)$ and expected heterozygosity $\left(H_{\mathrm{E}}\right)$ were calculated, and the degrees of genetic differentiation $\left(F_{\mathrm{ST}}\right)$ were analyzed by Genepop version 4.0.10 (Raymond and Rousset, 1995). A neighbor-joining method was used to construct a phylogenetic tree based on Nei's unbiased genetic distances, using the NTSYSpc version 2.1 software. Principal component analysis (PCA; SAS, 1998) was employed to test the reliability of the phylogenetic tree based on the average individual Dice genetic distance.

\section{RESULTS AND DISCUSSION}

\section{Genetic diversity}

The estimates of genetic diversity for functional alleles are summarized in Table 3, and for microsatellite markers in Table 4. Mean $H_{\mathrm{E}}$ ranged from 0.31 to 0.43 for functional genes and 0.78 to 0.83 for microsatellites. The $H_{\mathrm{E}}$ is the greatest possibility of heterozygosity in the population (Engelsma et al., 2010). Theoretically, the $H_{\mathrm{E}}$ of functional genes should be lower than for microsatellite makers due to the number of alleles. $H_{\mathrm{E}}$ for all functional gene loci was not over than 0.5 because the maximum heterozygosity at a biallelic locus cannot exceed 0.5 (Falconer and Mackay, 1996). The $H_{\mathrm{E}}$ for all microsatellite loci in Gallus spp was greater than 0.5, which was in agreement with Dorji et al. (2011).

\section{Table 3. Wright's fixation index $\left(F_{\mathrm{ST}}\right)$ for five fowl populations based on six functional gene loci.}

\begin{tabular}{|c|c|c|c|c|c|c|c|c|c|c|c|c|}
\hline \multirow[t]{2}{*}{ Functional gene } & \multicolumn{2}{|c|}{ GG } & \multicolumn{2}{|c|}{ GS } & \multicolumn{2}{|c|}{ PD } & \multicolumn{2}{|c|}{ BR } & \multicolumn{2}{|c|}{ WL } & \multirow[t]{2}{*}{$F_{\mathrm{ST}}$} & \multirow[t]{2}{*}{ Degree of differentiation } \\
\hline & $H_{\mathrm{o}}$ & $H_{\mathrm{E}}$ & $H_{\mathrm{o}}$ & $H_{\mathrm{E}}$ & $H_{\mathrm{O}}$ & $H_{\mathrm{E}}$ & $H_{\mathrm{O}}$ & $H_{\mathrm{E}}$ & $H_{\mathrm{o}}$ & $H_{\mathrm{E}}$ & & \\
\hline$\overline{H S P 70 / \mathrm{C}}$ & 0.49 & 0.50 & 0.58 & 0.50 & 0.67 & 0.49 & 0.10 & 0.16 & 0.33 & 0.36 & 0.13 & Moderate \\
\hline$H S P 70 / \mathrm{M}$ & 0.39 & 0.32 & 0.28 & 0.24 & 0.29 & 0.25 & 0.33 & 0.28 & 0.97 & 0.50 & 0.10 & Moderate \\
\hline VIPR-1 & 0.61 & 0.50 & 0.50 & 0.47 & 0.36 & 0.48 & 0.67 & 0.50 & 0.37 & 0.51 & 0.02 & Slight \\
\hline $24 b p P R L$ & 0.27 & 0.23 & 0.03 & 0.07 & 0.41 & 0.42 & 0.33 & 0.33 & 0.40 & 0.45 & 0.08 & Moderate \\
\hline$G H R$ & 0.46 & 0.49 & 0.24 & 0.52 & 0.20 & 0.40 & 0.00 & 0.11 & 0.00 & 0.44 & 0.20 & Strong \\
\hline$I G F-I$ & 0.02 & 0.02 & 0.28 & 0.28 & 0.05 & 0.05 & 0.39 & 0.50 & 0.30 & 0.29 & 0.21 & Strong \\
\hline Mean & 0.37 & 0.34 & 0.31 & 0.35 & 0.33 & 0.35 & 0.30 & 0.31 & 0.39 & 0.43 & 0.12 & Moderate \\
\hline
\end{tabular}

$\overline{\mathrm{GG}}=$ Gallus gallus; GS = G. g. spadiceus; $\mathrm{PD}=$ G. domesticus Pradu Hang Dam; $\mathrm{BR}=$ broilers; WL $=$ White Leghorns; $H_{\mathrm{O}}=$ observed heterozygosity; $H_{\mathrm{E}}=$ expected heterozygosity.

Low $H_{\mathrm{O}}$ (Table 3) may lead to positive assortment or a situation of high homozygosity. Selection for economic traits may have caused the low $H_{\mathrm{O}}$ of $\mathrm{C}_{1} \mathrm{C}_{2}$ in $\mathrm{BR}$ and the high $H_{\mathrm{O}}$ of $\mathrm{M}_{1} \mathrm{M}_{2}$ in WL, which are related to heat tolerance and heat susceptibility, respectively (Duangduen et al., 2008). Finally, loss of $H_{\mathrm{O}}$ of the GHR gene in BR and WL has occurred; this may reflect high selection pressure (Johansson et al., 2010). A reduction of heterozygosity can occur from inbreeding, and may result in a loss of alleles; commercial breeds have shown a lack of some alleles found in RJF (Muir et al., 2008). 
Table 4. Wright's fixation index $\left(F_{\mathrm{ST}}\right)$ for five fowl populations based on 18 microsatellite loci.

\begin{tabular}{|c|c|c|c|c|c|c|c|c|c|c|c|c|}
\hline \multirow[t]{2}{*}{ Microsatellite } & \multicolumn{2}{|c|}{ GG } & \multicolumn{2}{|c|}{ GS } & \multicolumn{2}{|c|}{$\mathrm{PD}$} & \multicolumn{2}{|c|}{$\mathrm{BR}$} & \multicolumn{2}{|c|}{ WL } & \multirow[t]{2}{*}{$F_{\text {ST }}$} & \multirow[t]{2}{*}{ Degree of differentiation } \\
\hline & $H_{\mathrm{O}}$ & $H_{\mathrm{E}}$ & $H_{\mathrm{O}}$ & $H_{\mathrm{E}}$ & $H_{\mathrm{O}}$ & $H_{\mathrm{E}}$ & $H_{\mathrm{O}}$ & $H_{\mathrm{E}}$ & $H_{\mathrm{o}}$ & $H_{\mathrm{E}}$ & & \\
\hline MCW0014 & 0.34 & 0.75 & 0.45 & 0.77 & 0.60 & 0.76 & 0.29 & 0.82 & 0.17 & 0.69 & 0.07 & Moderate \\
\hline MCW0034 & 0.24 & 0.83 & 0.48 & 0.80 & 0.87 & 0.85 & 0.41 & 0.82 & 0.33 & 0.78 & 0.05 & Slight \\
\hline MCW0037 & 0.17 & 0.81 & 0.19 & 0.76 & 0.52 & 0.83 & 0.21 & 0.78 & 0.50 & 0.79 & 0.02 & Slight \\
\hline MCW0069 & 0.13 & 0.79 & 0.19 & 0.81 & 0.73 & 0.77 & 0.24 & 0.79 & 0.60 & 0.77 & 0.04 & Slight \\
\hline MCW0081 & 0.87 & 0.90 & 0.70 & 0.91 & 0.97 & 0.92 & 0.70 & 0.90 & 0.89 & 0.84 & 0.01 & Slight \\
\hline MCW0104 & 0.43 & 0.87 & 0.14 & 0.84 & 0.70 & 0.88 & 0.56 & 0.88 & 0.50 & 0.79 & 0.04 & Slight \\
\hline MCW0111 & 0.67 & 0.89 & 0.71 & 0.88 & 0.73 & 0.86 & 0.46 & 0.88 & 0.30 & 0.86 & 0.03 & Slight \\
\hline MCW0123 & 0.66 & 0.88 & 0.55 & 0.90 & 0.87 & 0.91 & 0.73 & 0.88 & 0.76 & 0.90 & 0.01 & Slight \\
\hline MCW0183 & 0.24 & 0.76 & 0.26 & 0.65 & 0.47 & 0.78 & 0.46 & 0.70 & 0.60 & 0.78 & 0.01 & Slight \\
\hline MCW0222 & 0.43 & 0.80 & 0.17 & 0.86 & 0.34 & 0.80 & 0.15 & 0.61 & 0.77 & 0.80 & 0.09 & Moderate \\
\hline MCW0248 & 0.20 & 0.80 & 0.19 & 0.89 & 0.87 & 0.84 & 0.50 & 0.84 & 0.60 & 0.82 & 0.04 & Slight \\
\hline MCW0295 & 0.23 & 0.78 & 0.33 & 0.73 & 0.23 & 0.88 & 0.57 & 0.88 & 0.10 & 0.74 & 0.03 & Slight \\
\hline ADL112 & 0.13 & 0.73 & 0.13 & 0.56 & 0.31 & 0.63 & 0.27 & 0.72 & 0.03 & 0.74 & 0.10 & Moderate \\
\hline ADL147 & 0.53 & 0.81 & 0.45 & 0.83 & 0.47 & 0.82 & 0.40 & 0.81 & 0.21 & 0.66 & 0.05 & Slight \\
\hline ADL268 & 0.24 & 0.86 & 0.00 & 0.83 & 0.37 & 0.88 & 0.44 & 0.88 & 0.47 & 0.93 & 0.02 & Slight \\
\hline ADL0372 & 0.31 & 0.88 & 0.25 & 0.86 & 0.80 & 0.89 & 0.66 & 0.89 & 0.20 & 0.79 & 0.03 & Slight \\
\hline LEI0094 & 0.17 & 0.83 & 0.03 & 0.82 & 0.37 & 0.81 & 0.15 & 0.76 & 0.03 & 0.82 & 0.05 & Slight \\
\hline LEI0166 & 0.07 & 0.72 & 0.00 & 0.83 & 0.14 & 0.82 & 0.43 & 0.83 & 0.10 & 0.58 & 0.07 & Moderate \\
\hline Mean & 0.34 & 0.82 & 0.29 & 0.81 & 0.57 & 0.83 & 0.42 & 0.82 & 0.40 & 0.78 & 0.04 & Slight \\
\hline
\end{tabular}

$\mathrm{GG}=$ Gallus gallus; $\mathrm{GS}=$ G. g. spadiceus $; \mathrm{PD}=$ G. domesticus Pradu Hang Dam; $\mathrm{BR}=$ broilers; $\mathrm{WL}=$ White Leghorns; $H_{\mathrm{O}}=$ observed heterozygosity; $H_{\mathrm{E}}=$ expected heterozygosity.

\section{Genetic differentiation}

The genetic differences among five populations, as determined from functional genes and microsatellites, are described by the Wright fixation index $\left(F_{\mathrm{ST}}\right)$ in Table 3 . The $F_{\mathrm{ST}}$ value shows the degree of genetic differentiation; an $F_{\mathrm{ST}}$ value of 0.00 to 0.05 is slight, 0.05 to 0.15 is moderate, 0.15 to 0.25 is strong, and $>0.25$ is very strong genetic differentiation (Nassiry et al., 2009). According to this criterion, the $F_{\mathrm{ST}}$ from functional gene analysis showed moderate to strong differentiation for HSP70C, GHR, IGF-1, HSP70M, and 24bpPRL, and slight differentiation for VIPR-1. An $F_{\mathrm{ST}}$ of 0.15 is considered to be an indication of significant differentiation among populations (Dávila et al., 2009). Here, the average $F_{\mathrm{ST}}$ of functional genes was found to be 0.12 , indicating that genetic differentiation between RJF, PD and commercial lines has occurred to a moderate degree. The differentiation found in these subpopulations may be due to different genetic origins (Shahbazi et al., 2007), breeding systems (commercial lines experience high selection intensity, while there is random mating among TIC), chicken types and sample sizes (a small population of RJF).

On the other hand, microsatellites showed only a slight subpopulation division between populations, $F_{\mathrm{ST}}=0.04$ (Table 4 ). Although microsatellite markers show diversity scattered along the entire genome, they could be conservative in demonstrating changes and may exclude the improvement of some genes. Microsatellites may be appropriate for identifying genetic diversity within a population or for comparing such diversity between populations. In terms of genetic differentiation, using selective functional genes provides sufficient information to depict genetic characteristics among populations with reasonable $F_{\mathrm{ST}}$, especially when dynamic allele frequency distributions of such functional genes have been previously hypothesized. 


\section{Phylogenetic relationships}

A phylogenetic tree was reconstructed exclusively based on Nei's unbiased genetic distance. It showed that trees from functional genes (Figure 1A) and microsatellites (Figure 1B) for five fowl populations can be clustered into three groups: CC was split into two groups, egg type (WL) and meat type (BR), while PD represented the same group as RJF. This result is in agreement with functional (calpain gene) polymorphisms of Southeast Asian native chickens (Okumura et al., 2006), and 20 microsatellites that showed that indigenous chickens had spilt from CC (Dorji et al., 2011). A similar conclusion was drawn for Rhode Island Red and Northeast Ethiopian native chickens (Hassen et al., 2009). The findings from microsatellite analysis confirmed that egg layers (WL) and commercial BR formed different clusters; this might be related to the history and purpose of development of 12 commercial lines (Tadano et al., 2007). The broiler line is different in genetic composition (Emara et al., 2002) for purposes of growth; thus the grouping was distinctly separate from that of egg layers (Tadano et al., 2007).

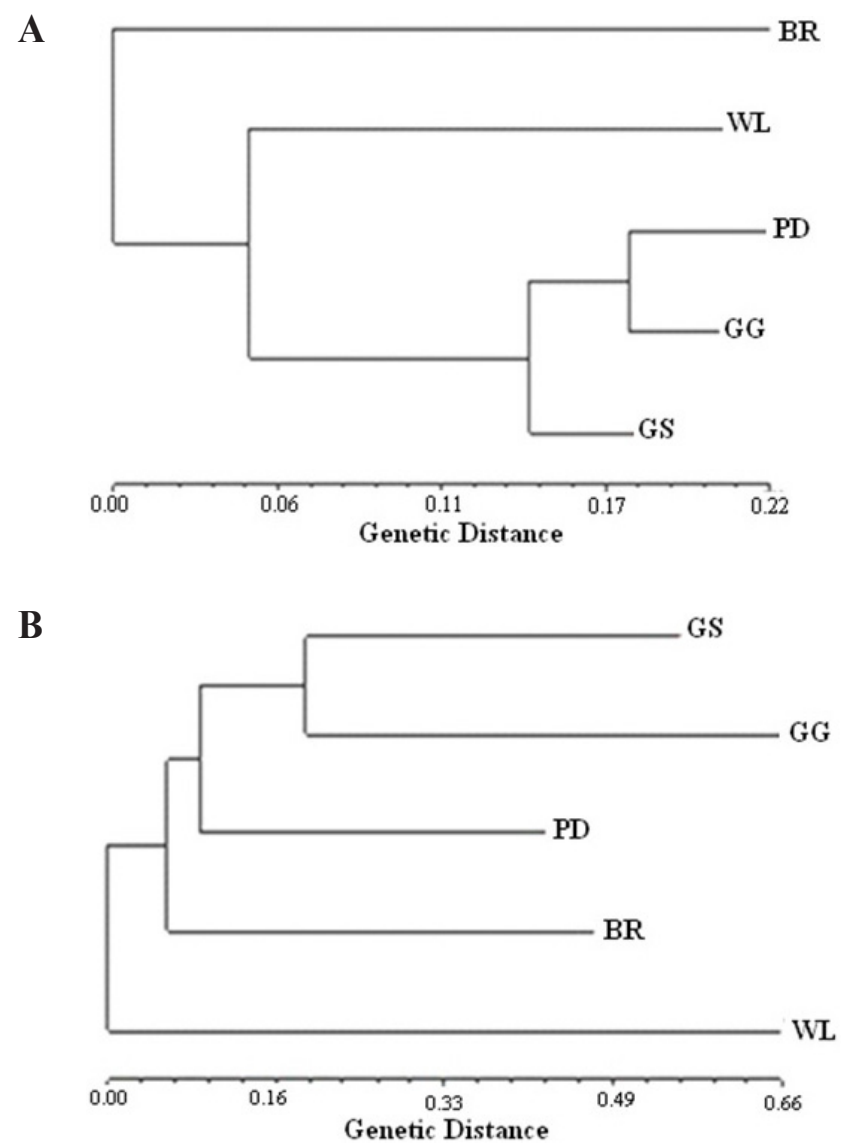

Figure 1. Phylogenetic tree based on Nei's unbiased distance from six loci. A. Functional genes and B. Eighteen microsatellite markers for Gallus gallus (GG), G. g. spadiceus (GS), Pradu Hang Dam (PD), broiler (BR), and White Leghorn (WL). 
GG is believed to be the original domestic chicken (Fumihito et al., 1994), and our study showed that the functional genes of PD were close to GG. On the other hand, microsatellites showed GG close to GS; the reason may be that GG and GS are the same species $(G$. gallus), hence GS has little genetic difference from GG.

PD and CC descended from the same ancestor. However, CC developed from a low effective population number, followed by intensive selection. Thus, $\mathrm{CC}$ has genetic differences from PD. On the other hand, PD was closer to RJF; this may be due to random mating among PD, which avoids selection. Hence, it might be assumed that there was less genetic change in PD than in CC.

\section{PCA}

To check the clustering pattern found for the five fowl populations, we also analyzed individual similarity using Dice's coefficient based on PCA.

The principal component plot from six functional genes (Figure 2A) was consistent with the phylogenetic tree (Figure 1A), and showed a clear segregation of all fowl populations into different quadrants of the plot: WL and BR (lower left and upper left, respectively) were clearly discriminated from RJF and PD, for the reasons stated above. However, the plot from microsatellites (Figure 2B) was different from the phylogenetic tree (Figure 1B) and the plot of functional genes (Figure 2A).

A



B

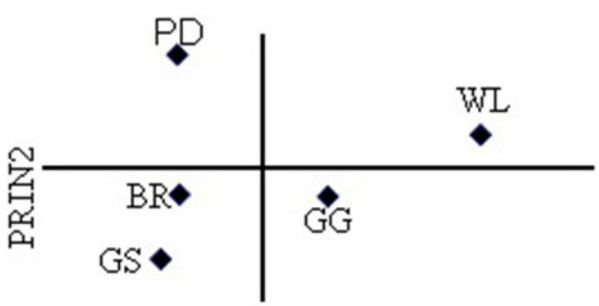

PRIN1

Figure 2. Two-dimensional principal component plots among five populations based on A. Dice's genetic similarity coefficients for six loci of functional genes and B. Eighteen microsatellite markers for Gallus gallus (GG), G. $g$. spadiceus (GS), Pradu Hang Dam (PD), Broiler (BR), and White Leghorn (WL).

The PCA plot has been widely used in biostatistics (Faes et al., 2001). Okumura et al. (2006) showed genetic variation at the calpain loci, with clear separation of WL and BR from 
the local chicken. However, results from microsatellites may be the weak point in the determination of genetic variation in selected genetic populations.

\section{CONCLUSIONS}

The phylogenetic tree and principal component plots derived from microsatellites and functional genes were similar. Overall, the genetic comparison for RJF, PD and CC with functional genes was highly efficient in detecting genetic differences between populations. Thus, the appropriate set of functional genes may be regarded as useful tools, taking into consideration populations that are under different degrees of selection.

\section{ACKNOWLEDGMENTS}

The authors thank the Department of National Parks, Wildlife Conservation Office; the Department of National Parks, Chulabhorn Wildlife Breeding Center, and Khao Kho Wildlife Captive Breeding Center; the Department of Livestock Development Research Center; the Research and Development Network Center for Animal Breeding (native chicken), and the Khon Kaen University farm, for supplying blood samples. Research supported by the Higher Education Research Promotion and the National Research University Project of Thailand, Office of the Higher Education Commission, through the Food and Functional Food Research Cluster of Khon Kaen University.

\section{REFERENCES}

Beigi Nassiri MT, Hamidi Z and Tavakoli S (2007). The investigation of genetic variation at microsatellite loci in Mazandaran native chickens. Int. J. Poult. Sci. 6: 675-678.

Cui JX, Du HL, Liang Y, Deng XM, et al. (2006). Association of polymorphisms in the promoter region of chicken prolactin with egg production. Poult. Sci. 85: 26-31.

Dávila SG, Gil MG, Resino-Talavan P and Campo JL (2009). Evaluation of diversity between different Spanish chicken breeds, a tester line, and a White Leghorn population based on microsatellite markers. Poult. Sci. 88: 2518-2525.

Delany ME (2003). Genetic Diversity and Conservation of Poultry. In: Poultry Genetics, Breeding and Biotechnology (Muir WM and Aggrey SE, eds.). CABI Publishing, Wallingford, 257-281.

Dorji N, Daungjinda M and Phasuk Y (2011). Genetic characterization of Thai indigenous chickens compared with commercial lines. Trop. Anim. Health Prod. 43: 779-785.

Duangduen C, Duangjinda M, Katavatin S and Aeagwanich W (2008). Effect of hsp70 Genotypes on Thermotolerance in Thai Native Chicken and Broilers. Proceedings of the 4th Symposium on Thermotolerance in Domestic Animals. Khon Kaen, 241-245.

Emara MG, Kim H, Zhu J, Lapierre RR, et al. (2002). Genetic diversity at the major histocompatibility complex (B) and microsatellite loci in three commercial broiler pure lines. Poult. Sci. 81: 1609-1617.

Engelsma KA, Calus MP, Bijma P and Windig JJ (2010). Estimating genetic diversity across the neutral genome with the use of dense marker maps. Genet. Sel. Evol. 42: 12.

Faes L, Nollo G, Kirchner M, Olivetti E, et al. (2001). Principal component analysis and cluster analysis for measuring the local organisation of human atrial fibrillation. Med. Biol. Eng. Comput. 39: 656-663.

Falconer DS and Mackay TFC (1996). Introduction to Quantitative Genetics. 4th edn. Pearson Education Ltd., Harlow.

FAO/ISAG (Food and Agriculture Organization of the United Nations/International Society for Animal Genetics) (1998). Secondary Guidelines for Development of National Farm Animal Genetic Resources Management Plans. Measurement of Domestic Animal Diversity (MoDAD): Recommended Microsatellite Markers. Available at [http:// dad.fao.org/en/refer/library/guidelin/marker]. Accessed July 13, 2007.

Fumihito A, Miyake T, Sumi S, Takada M, et al. (1994). One subspecies of the red junglefowl (Gallus gallus gallus) suffices as the matriarchic ancestor of all domestic breeds. Proc. Natl. Acad. Sci. U. S. A. 91: 12505-12509. 
Goodwin W, Linacre A and Hadi S (2007). An Introduction to Forensic Genetics. John Wiley \& Sons Ltd., Chichester. Goudet J (2002). FSTAT version 2.9.3.2. Department of Ecology and Evolution. University of Lausanne, Lausanne.

Hassen H, Neser FWC, de Kock A and van Marle-Köster E (2009). Study on the genetic diversity of native chickens in northwest Ethiopia using microsatellite markers. Afr. J. Biotechnol. 8: 1347-1353.

Hillel J, Groenen MA, Tixier-Boichard M, Korol AB, et al. (2003). Biodiversity of 52 chicken populations assessed by microsatellite typing of DNA pools. Genet. Sel. Evol. 35: 533-557.

Johansson AM, Pettersson ME, Siegel PB and Carlborg Ö (2010). Genome-wide effects of long-term divergent selection. PLoS Genet. 6: 1-12.

Li HF, Zhu WQ, Chen KW, Wu X, et al. (2008). Associations between GHR and IGF-1 gene polymorphisms and reproductive traits in Wenchang chickens. Turk. J. Vet. Anim. Sci. 32: 281-285.

Li HF, Shu JT, Song WT and Chen KW (2009). Analysis of genetic diversity in Qingyuan partridge chickens based on microsatellite markers. J. Anim. Vet. Adv. 8: 454-458.

Muir WM, Wong GKS, Zhang Y, Wang J, et al. (2008). Genome-wide assessment of worldwide chicken SNP genetic diversity indicates significant absence of rare alleles in commercial breeds. Proc. Natl. Acad. Sci. U. S. A. 105: 17312-17317.

Nassiry MR, Javanmard A and Tohidi R (2009). Application of statistical procedures for analysis of genetic diversity in domestic animal populations. Am. J. Anim. Vet. Sci. 4: 136-141.

Niu D, Fu Y, Luo J, Ruan H, et al. (2002). The origin and genetic diversity of Chinese native chicken breeds. Biochem. Genet. 40: 163-174.

Okumura F, Shimogiri T, Kawabe K, Okamoto S, et al. (2006). Gene constitution of South-East Asian native chickens, commercial chickens and Jungle fowl using polymorphisms of four calpain genes. Anim. Sci. J. 77: 188-195.

Raymond M and Rousset F (1995). GENEPOP version 4.0.10. Available at [http://genepop.curtin.edu.au/]. Accessed February 24, 2011.

Rosenberg NA, Burke T, Elo K, Feldman MW, et al. (2001). Empirical evaluation of genetic clustering methods using multilocus genotypes from 20 chicken breeds. Genetics 159: 699-713.

SAS 6.12 (1998). SAS Institute Inc., Cary.

Shahbazi S, Mirhosseini SZ and Romanov MN (2007). Genetic diversity in five Iranian native chicken populations estimated by microsatellite markers. Biochem. Genet. 45: 63-75.

Soller M, Weigend S, Romanov MN, Dekkers JC, et al. (2006). Strategies to assess structural variation in the chicken genome and its associations with biodiversity and biological performance. Poult. Sci. 85: 2061-2078.

Tadano R, Nishibori M, Nagasaka N and Tsudzuki M (2007). Assessing genetic diversity and population structure for commercial chicken lines based on forty microsatellite analyses. Poult. Sci. 86: 2301-2308.

Weigend S and Romanov MN (2001). Current strategies for the assessment and evaluation of genetic diversity in chicken resources. World's Poult. Sci. J. 57: 275-288.

Zhou H, Mitchell AD, McMurtry JP, Ashwell CM, et al. (2005). Insulin-like growth factor-I gene polymorphism associations with growth, body composition, skeleton integrity, and metabolic traits in chickens. Poult. Sci. 84: 212-219.

Zhou M, Lei M, Rao Y, Nie Q, et al. (2008). Polymorphisms of vasoactive intestinal peptide receptor-1 gene and their genetic effects on broodiness in chickens. Poult. Sci. 87: 893-903. 